\title{
THE GAZE AND THE MIRROR: VISION, DESIRE, AND IDENTITY \\ IN GÓNGORA'S \\ FÁBULA DE POLIFEMO Y GALATEA
}

\section{Mary E. Barnard \\ Pennsylvania State University}

$\mathrm{V}$

ision was the highest and noblest of the senses for early modern poets and philosophers alike. The eyes - transparent windows of the soul - were master organs of intellectual, emotional, and spiritual transactions (Branna Perlman 113). Góngora's Polifemo, a poem full of eyes and brilliant spectacles, illustrates this primacy of vision. In this essay I will focus on the gaze and the mirror to examine the connection between vision and desire in the fashioning of the identity of the text's three lovers: the monster Polyphemus, his beloved Galatea, and the rival Acis. ${ }^{1}$ Gongora's text exhibits both the male and the female gaze. The spectator/object relation is reciprocal and fetishization is applied to both sexes. ${ }^{2}$ Voyeurism, exhibitionism, selfreflexivity, and melancholia are all engaged in the poetics of sight and desire. To explore Góngora's use of vision in its various modes, I bring into my analysis theories of optics from the classical and early modern periods, as well as psychoanalysis, particularly Sigmund Freud's notions of scopophilia and Jacques Lacan's concept of the "mirror stage."

The specular play begins in stanza 24 when Acis, all dust and sweat in the midsummer heat, enters the secluded spot where Galatea lies sleeping by the fountain. He looks at her eyes ("ambas luces bellas") closed by sleep and, while drinking from the fountain waters, continues to look at her out of the corner of his eye: "su boca dio, y sus ojos cuanto pudo, / al sonoro cristal, al cristal mudo" (191-92). In casting his eyes on Galatea's silent body ("cristal mudo"), Acis enters a world of visual enticement, of woman as erotic spectacle. Laura Mulvey has observed: "In their traditional exhibitionist role women are simultaneously looked at and displayed, with their appearance coded for strong visual and erotic impact. ... Woman displayed as sexual object is the leitmotif of erotic spectacle:... [S] he holds the look, and plays to and signifies male desire" (19). In Góngora's text, Galatea's body is at once a magnet drawing Acis's greedy eyes and an idol to be adored: "El bello imán, el ídolo dormido, / que acero sigue, idólatra venera" 
(25.197-98). Spectacle and desire are neatly combined to fashion Acis's identity as idolatrous lover.

The "lust of the eyes" has been the subject of extensive theoretical discussion since Plato's Phaedrus. In the early modern period, it is a topos in which seeing and desiring are intimately linked. Marsilio Ficino, for example, in his Commentary to Plato's Symposium, privileges sight as the sense that gives birth to desire: love begins with a visual wounding when gazes engage (161-62). But in the Polifemo, Acis does not engage Galatea's eyes; he is seduced instead by her beauty. The notion that desire is evoked in the singular act of contemplating beauty is a central aspect of the early modern psychology of love. The serious erotic lyric of Góngora's age takes in earnest what Andreas Capellanus offers perhaps in jest in his ironic view of love in De amore $\left(12^{\text {th }} \mathrm{C}\right)$. "Love," writes Capellanus, "results from the sight of, and uncontrollable thinking about, the beauty of the other sex.... [I]t arises not from any action, but solely from the thought formed by the mind as a result of the thing seen" (32-35). There are certain echoes of Plato's Phaedrus in Capellanus's text. Plato placed beauty in intimate relation to vision in his discussion of eros: "[We] apprehend [beauty] through the clearest of our senses, clear and resplendent. For sight is the keenest mode of perception" (250 D). Sight is the active agent of desire, as we read in another passage of the Phaedrus: "[W]hen one ... beholds a godlike face or bodily form that truly expresses beauty, first there comes upon him a shuddering and a measure of that awe which the vision inspired, and then reverence as at the sight of a god" (251 A). Plato's Phaedrus (along with the Symposium) is at the root of the Neoplatonic concept of the ascent of the soul from a vision of terrestrial beauty to that of the godhead. In Góngora's Polifemo, Galatea is conceived as a kind of "goddess," but Acis, like his sleeping idol, remains firmly "on the ground." Beholding the beauty of the beloved does not elicit a sight of the divine in the lover. There is no Neoplatonic surge towards heaven in Góngora's passage.

As he surveys the body of lovely Galatea, Acis is constituted as a voyeur. He enacts what has been called in psychoanalysis 'scopophilia,' theorized by Sigmund Freud as one of the component instincts of sexual drives. In "Instincts and Their Vicissitudes," Freud outlines three stages to the workings of scopophilia: in the first, pleasure resides in the act of looking at a person as an erotic object; in the second, the subject gives up the other as object and turns his attention to a part of his own body; in the third, the subject becomes, in narcissistic exhibitionism, the object of another's look (14:129). Acis enacts the first and third stages (the first here; the third below). ${ }^{4}$ As he pleasurably focuses his attention on Galatea, her body emerges as the brilliant, idealized ob- 
ject on which his very identity as voyeuristic idolater depends. She is depicted through catachreses in the form of exaggerated metaphors: "cristal mudo," "bello imán," "ídolo dormido." Acis's look transforms Galatea into the desired object, and the catachreses in their "hyperbolic visibility" specularize her in a second and more profound way: they create a visual display for the reader, who becomes a spectator, along with Acis. At first, however, this specularization seems to be called into question by the very trope that describes Galatea. It may be argued that Góngora's catachreses, deprived as they are of their referent, are characterized by remote analogies and a highly precious language behind which Galatea remains "hidden." Catachresis seems to be the reverse of enargeia, the rhetoric of presence premised on the union of res and verba, and so a means to endow language with the capacity to bring things "before the eyes." ${ }^{5}$ Erasmus, connecting visual and verbal acts, instructs the writer to achieve enargeia by rendering a description of a thing so as to "display it to be looked at as if it were expressed in color in a picture, so that it may seem that we have painted, not narrated, and that the reader has seen, not read" (2.217; trans in Cave 28-29). For this task Erasmus proposes select figures of speech, including metaphor.

But if Góngora's catachreses as metaphors do not readily effect the graphic immediacy called for by enargeia, they succeed nonetheless in presenting Galatea's reified body in all its visual and erotic force as a splendid spectacle, silent and still, firmly holding the reader's look. These catachreses successfully evoke Galatea's body because within the economy of the text, as Paul Julian Smith observes about the catachreses depicting the nymph's complexion ("púrpura nevada, o nieve roja," 14.108), they engage a "formalized and autonomous code of representation" that need not "depend on the real" ("The Polifemo" 64). ${ }^{6}$ This code creates a logic of its own that (in interrelation with other images in the poem) allows us to decipher what would otherwise remain undecipherable. Like "púrpura nevada," which describes Galatea's white and rosy flesh, "cristal mudo" of stanza 24 (in an interplay with the shining, flowing waters as "sonoro cristal") offers another visually potent image: the silent nymph's brilliant, white body.? The two images, "bello imán" and "ídolo dormido," that follow in stanza 25 reinforce Galatea's compelling presence as object of contemplation under the reader's intense surveillance, paralleling Acis's own. The specular display of the nymph's body is mimicked playfully by the wind, which becomes delicately complicitous in the act. As it blows gently over Galatea, it is as if it were drawing back the invisible curtains of her bed, made of grass and shade: 
Vagas cortinas de volantes vanos

corrió Favonio lisonjeramente

a la (de viento cuando no sea) cama

de frescas sombras, de menuda grama. $(27.213-16)^{8}$

Awakened from her sleep by the sound of the fountain waters, Galatea finds the gifts Acis has left for her. Moved by desire (as Cupid strikes her breast with a gold dart), her eyes now awaken: "mira la ofrenda ya con más cuidado" (31.246; my emphasis). Galatea's eyes had been privileged by the lyric speaker, who in stanza 13 initiates the catalogue of her beauty traits through the typical early modern reification and fragmentation of the female body (starting with the eyes, as seen below, followed by her pearly-white brow and ear in stanza 14). The fetishization of the nymph, with its scattering of exquisite body parts, points to the idealization of her beauty but also marks her vulnerability as the object of desire. ${ }^{9}$

Ninfa, de Doris hija, la más bella, adora, que vio el reino de la espuma. (...)

Son una y otra luminosa estrella

lucientes ojos de su blanca pluma:

si roca de cristal no es de Neptuno,

pavón de Venus es, cisne de Juno. (13.97-98, 101-104)

Numerous interpretations have pointed out the exaltation of Galatea's eyes, gleaming like stars against her white skin, an image centering on the extravagant exchange of attributes in the interplay of Venus's swan (its whiteness) and Juno's peacock (the luminous eyes in its feathers). ${ }^{10}$ Galatea's eyes, which had turned away from Polyphemus in scorn, now become active agents in a love adventure that begins as she surveys Acis's "ofrenda." ${ }^{11}$ Though she cannot name the invisible "dueño" of these gifts, she sees him tenuously in her visual imagination, sketched by a gentle brush: "pincel süave / lo ha bosquejado ya en su fantasía" (32.251-52). ${ }^{12}$

Then she finds him. Feigning sleep, Acis solicits Galatea's look, exhibiting his body for her contemplation and thus enacting the next stage of his scopophilic game. Galatea looks on, adopting the role of voyeur as she pleasurably gazes at Acis, who now becomes the object of contemplation and desire. The sketch drawn by Cupid in her imagination she now sees in full color (34.269-72). Acis's body is reified and fetishized as hers had been earlier: sun for his hair, flowers for his downy beard (35.277-80). Feminine traits depict a masculine beauty that in exhibitionist performance firmly holds the woman's look ("atenta mira," 273) and, in a singular reversal, "plays to" and signifies female 
desire. In stanza 33 the lyric narrator makes clear that Galatea, poised motionless over Acis, still as an eagle about to descend on a fledgling kite, does not understand the silent rhetoric of his feigning, his cunning act: "bárbara al mentido / retórico silencio que no entiende" (259$60)$. He is all spectacle, she all eyes, drinking in the love poison through a visual "drinking in" of his image. Seeing and desiring are fused in one powerful act that places her sexual urgency in relief:

en lo viril desata de su vulto

lo más dulce el Amor, de su veneno;

bébelo Galatea, y da otro paso

por apurarle la ponzoña al vaso. (36.285-88)

But Acis, too, is all eyes. Through half-closed eyes, he looks back intensely at Galatea: "Argos es siempre atento a su semblante" (37.292). In classical mythology, Argus was the ever-waking, hundred-eyed creature chosen by jealous Juno to spy on Io, the nymph loved by Jupiter, who turned her into a heifer. Argus was killed by Mercury, who lulled him to sleep and severed his head. In the Greek poet Moschus, a peacock springs from Argus's blood (2.58ff). In Ovid's Metamorphoses, Juno sets Argus's eyes on the feathers of her peacock (1.723-24). The reciprocity evident in the visual pleasure that the lovers take in each other is now captured imagistically: Acis is identified with the creature whose luminous eyes (the root arg means "bright"; Ovid called Argus "stellatus Argus" 'star-eyed Argus,' 664) appear on the plumage of Juno's peacock, the bird identified with Galatea in order to celebrate her eyes, shining like stars against the whiteness of her skin. But no amount of reciprocity can hide the fact that Acis has the upper hand.

Acis looking at Galatea is not only an Argus watching her every move but also a lynx reading her every thought: "lince penetrador de lo que piensa, / cíñalo bronce o múrelo diamante" (37.293-94). Acts of looking and desiring are accompanied by the act of knowing. Early modern writers drew an intimate relation between seeing and knowing. Tesauro equates vision and cognition: "To look with the eyes and to contemplate with the intellect are two analogous types of knowledge." ${ }^{13}$ Leon Battista Alberti's theories of optics in De Pictura (ca.1435) go one step further, placing seeing and knowing in a relation of power. The geometrical analysis of the visual field in Alberti's theory of perspective, with its centrally fixed "vanishing point," yields epistemological mastery: "eye and knowledge come together; subject, object and the distance of the steady observation that allows the one to master the other" (Heath 30). In Góngora's text, knowledge connected with vision enters the erotic field as a product of the overriding power 
of desire. The seventeenth-century Góngora commentator Pedro Díaz de Rivas writes: "Dice que cautamente estaba penetrando los íntimos pensamientos de Galatea, porque tal es la fuerza del amor, que le da al amante perspicacia para que conozca lo interior aunque la persona amada fuera una estatua immoble de bronce o diamante que no hiciera acto exterior por donde se conocieran los interiores" (Discursos apologéticos por el estilo del Poliphemo y Soledades, 1624; in Alonso 3:190).

Even though Galatea's predatory gaze of stanza 33 signals a kind of mastery, as she is obliquely identified with the eagle ("ave reina"), converting Acis into both object and prey, he is the true predator and she the prey. Unlike the nymph who, in looking at her lover, does not understand his silent, deceptive game, Acis's eroticized seeing encompasses acuteness of vision and of insight, both emblematized in the figure of the lynx - a commonplace in Golden Age texts. ${ }^{14}$ Acis's knowledge of Galatea's secret thoughts, signaling his mastery over the nymph, is a prelude to possession; anticipated by the telling "penetrador" that qualifies the lynx, it is played out in the couple's love-making in stanzas 40-42. Galatea, the "monstro de rigor, la fiera brava" (31.245) to her previous suitors, including Polyphemus, now gives herself to Acis. Conceived as a figure of mobility, Galatea's identity is "fluid," "always poised for departure" as she moves "from sea to land and back to sea again" (Dolan 101). "Fugitiva ninfa," she flees her eager suitors (23.177), escaping in swift flight as if propelled by feathers ("calzada plumas," 16.127). Galatea's identity, however, shifts at the moment Acis enters the scene. Even though she reveals her elusive nature when her arms ("fugitivo cristal," 41.328) playfully escape her lover as she coyly resists his sexual advances, she is anchored at least for a moment to their nuptial bed ("tálamo) in that identity that has been provided to her by a desire she cannot contain or reject, brought to her by Acis, himself a figure of boundless yet cunningly orchestrated desire.

Despite intimations of an inner life in Acis and Galatea - the sketching of his figure in her imagination, her feelings as she hovers over him by turns agitated and hesitant, his reading of her thoughts - the lovers remain closed vessels, essentially bodies divested of interiority. Veiled by a highly metaphorical language, they exist as specular objects; in their visual, silent loveliness they are "all surface, all text." ${ }^{15}$ In Ovid's Metamorphoses we hear Galatea's voice in her role as narrator of the tale, but in Góngora's text only Polyphemus is endowed by the lyric speaker with voice and subjectivity. The silence of Acis and Galatea magnifies the oral performance of the Cyclops (Friedman 69). Polyphemus looks inward in melancholic self-reflection. His song, full of sadness and self-praise, is above all an entreaty to Galatea, a call for her presence and gaze. Following Ovid, Góngora draws a Polyphemus 


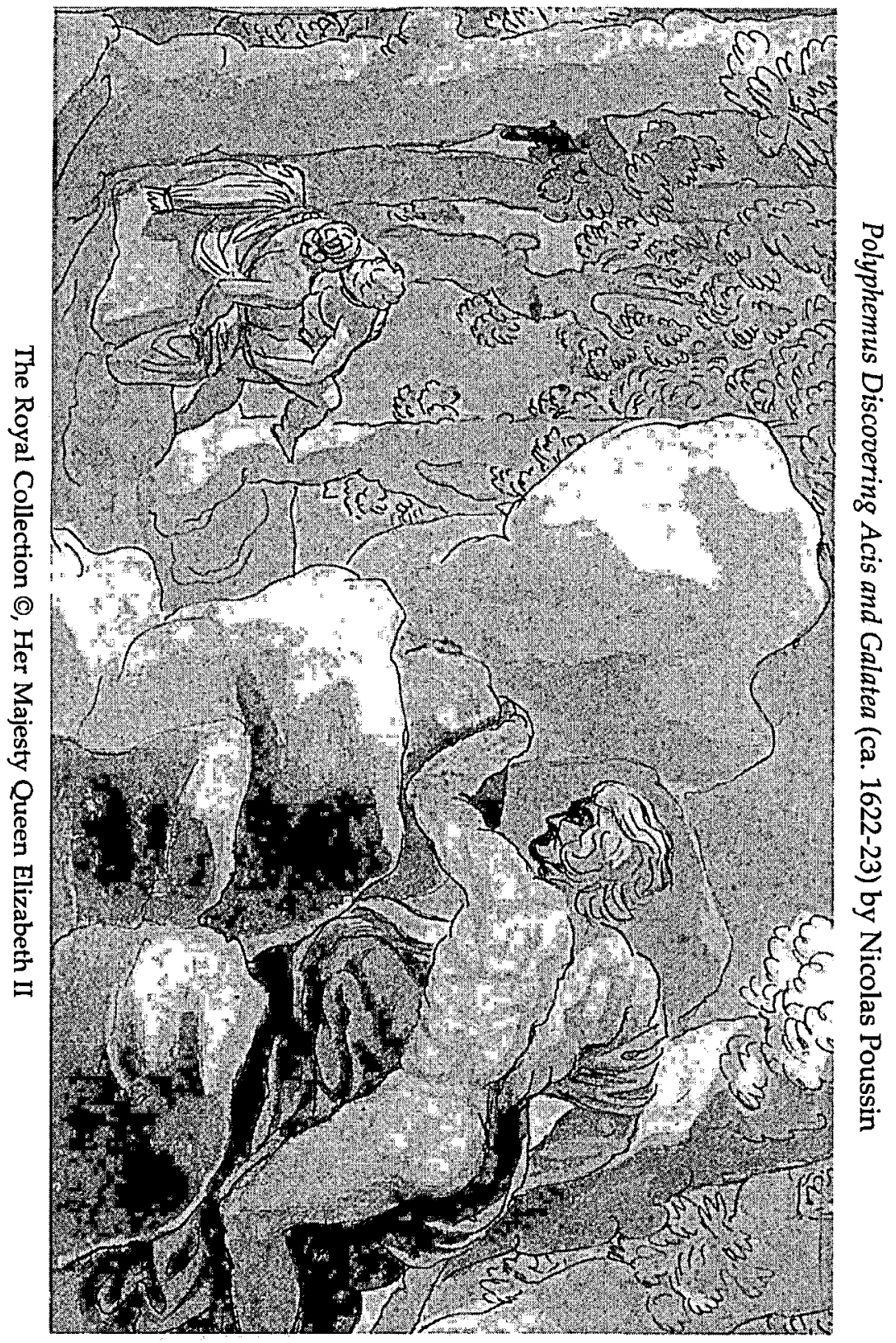


with attributes of both the Theocretian shepherd and the savage Cyclops of Homeric epic. In Ovid's text, the self-pitying lover's lament of sorrow and boasting mingles with rage: he promises Galatea that he will tear Acis "limb from limb and scatter the pieces over" her "waves" (13.865-66), and adds "I seem to be carrying Aetna in my breast with all its violence" (868-69). In Góngora's poem, Polyphemus's lament does not reveal his rage; the monster appears softer, more vulnerable, even tender, as he exposes his inner self to Galatea, exalts his body and makes it into a spectacle for her eyes. In praising her beauty and asking her to leave her dwelling place among the waves, vision is privileged:

"Deja las ondas, deja el rubio coro de las hijas de Tetis, y el mar vea, cuando niega la luz un carro de oro, que en dos la restituye Galatea." (47.369-72)

The sea would witness ("el mar vea") the miracle of two eyes restoring light to a world darkened by the gold chariot of the sun descending into the horizon. But for all the flattery, what the Cyclops has in mind for Galatea's eyes is none other than himself; the sea becomes the reflecting surface for his narcissistic act: "espejo de zafiro fue luciente / la playa azul, de la persona mia" (53.419-20; my emphasis). Narcissism flows from Polyphemus's melancholia.

In the early modern period, love melancholy is manifested as a physical and psychological condition, resulting from a deep sense of loss. It is "an affliction of the soul" accompanied by both sorrow and exultation, and characterized by an intense awareness of the self. Melancholia is ascribed above all to the contemplative brooder, exemplified most tellingly in Petrarch's solitary wanderer of the Rime sparse, who "alone and filled with care" ('solo e pensoso') in sonnet 35 walks through deserted fields, "with steps delaying and slow" ('passi tardi et lenti'). But this distressing condition is also a sign of genius, of inspiration and creativity. According to Marsilio Ficino's astral magic, Saturn, the highest of the planets under whose influence the melancholic is born, is a dark and malevolent star but also a "iuvans pater of men of intellect" (Klibansky, Panofsky, and Saxl 254). ${ }^{16}$ In response to an accusatory letter from his friend Giovanni Cavalcanti, Ficino writes, "if it should be necessary that [the melancholic temperament] does issue from Saturn, I shall, in agreement with Aristotle, say that this nature is a unique and divine gift" (Letters 2:34). Ficino gave shape to melancholia as the exclusive subjectivity of the man of letters. Modern psychoanalysis also interprets melancholia according to a double 
formula. In "Mourning and Melancholia" (1917), Sigmund Freud writes of the afflicted as "poor and empty," one who reveals "an extraordinary diminution in his self-regard" (14:246). But Freud's melancholic is also a narcissist, exuberant in his eloquence. In insistent self-criticism, he needs to speak out, finding "satisfaction in self-exposure," a kind of "narcissistic pleasure" in self-display. "It is what we call an accredited pathology," writes Juliana Schiesari of Freud's assessment, "justified by the heightened sense of conscience that the melancholic is said to display ostentatiously" (9; emphasis in original). Placing himself at the center of a scene of loss and eloquently voicing his discontent, Freud's melancholic projects himself as someone of exceptional qualities, much like Ficino's celebrated, creative melancholic.

Góngora's desiring Polyphemus belongs to this Ficinian-Freudian double scene. Perched on a high rock, the solitary Cyclops takes much pleasure in displaying his sorrow and sense of loss in an exhibitionist performance that also reveals a praiseworthy lover and poet. The disdainful Galatea causes his inner diminishment, its signs evident in sighs and tears in his declamation of pain: "Sorda hija del mar, cuyas orejas / a mis gemidos son rocas al viento" (48.377-78). His tears are as abundant as the milk from his flock: "leche corren y lágrimas; que iguales / en número a mis bienes son mis males" (49.391-92). Yet alongside this broken self, the slightly ridiculous and not so delicate seducer fashions an inflated, narcissistic image in a singular spectacle for the absent Galatea. Flaunting his lineage as the son of Neptune, he proclaims his name "Polifemo te llama, no te escondas" (51.405) and boasts that a groom so strong had never before been seen by Phoebus ("cual otro no vio Febo," 407). He admires his voice, "escucha un día / mi voz, por dulce, cuando no por mía" (48.383-84) and his possessions. In praising his stature, he portrays himself as a poet, his pen a finger writing his sorrow in the sky: "y en los cielos, desde esta roca, puedo / escribir mis desdichas con el dedo" (52.415-16). A Cyclopean man of letters, Polyphemus would write in the heavens, as on a blank page, what he now laments with his mellifluous voice. ${ }^{17}$ But for his most exalted celebration, he presents a fetish to Galatea to admire and perhaps love, his eye:

"Miréme, y lucir vi un sol en mi frente, cuando en el cielo un ojo se veía: neutra el agua dudaba a cuál fe preste, o al cielo humano, o al cíclope celeste." (53.421-24)

The waters mirror the imagined beauty of this urgent lover, who is both subject and object, spectator and spectacle, as in the ancient myth 
of Narcissus. In this narcissistic specular moment, Polyphemus proclaims himself a "celestial cyclops." Having robbed the sky of its sun, he places it on his forehead, reducing the sun to a mere eye. In the process, as Kathleen Dolan suggests, "he creates a myth of the self, a fantasy of a solar, divine identity which is a source of light and vision" (91). This idealized image reflected in the water carries implications regarding self-love and self-knowledge, and self-deception as well. In Jacques Lacan's "mirror stage," it is the joyful moment when the child, reflected in a mirror or in the gestures of its mother or others, sees itself whole for the first time (Écrits 1-7). This experience of plenitude, according to Lacan, inaugurates a series of specular moments where individuals "seek and foster the imaginary wholeness of an 'ideal ego"" (Bowie 106). For the rejected Polyphemus this is such a moment, an instance of healing when he can imagine himself in full mastery, complete and restored. "Miréme" is a call to Galatea to see him as he wants to be seen: not as a monstrous one-eyed Cyclops but as a heavenly being whose eye, seductive and irresistible in its luminosity, is a thing of beauty. In effect, he seeks to rectify Galatea's image of him. He seeks as well to refocus the lyric speaker's portrayal of his eye as almost, but not quite like the sun: "de un ojo ilustra el orbe de su frente, / émulo casi del mayor lucero" (7.51-52; my emphasis). Polyphemus makes the sea an accomplice in his self-celebration, the waters validating in indecision his vision of himself: "neutra el agua dudaba a cuál fe preste / o al cielo humano, o al cíclope celeste."

Polyphemus's self-fashioning depends on self-praising moments from earlier Polyphemus figures, stretching from Theocritus, Ovid, and Virgil to early modern reworkings such as Garcilaso's Eclogue I, Giambattista Marino's Polifemeide, and Luis Carrillo y Sotomayor's Fábula de Polifemo y Galatea. ${ }^{18}$ The original source of Polyphemus's looking into the waters is Theocritus' Sixth Idyll where Damoetas, in a singing contest with Daphnis, impersonates the Cyclops: "But lately I was looking into the sea, when all was calm; beautiful seemed my beard, beautiful my one eye" (37). The solar metaphor linked to Polyphemus's eye is supplied by Virgil and Ovid. In Virgil's Aeneid, Achaemenides, one of Odysseus's companions, relates how to escape the Cyclops's cave, they had to pierce his enormous eye, which he likens to "an Argive shield or the lamp of Phoebus" (3.637). In Ovid's Metamorphoses, Polyphemus, his reflection in the waters a moment of self-knowledge ("Surely I know myself ... I liked my features when I saw them," 13.840-41), justifies to Galatea his single eye with an allusion to the sun: "And what of that? Doesn't the great sun see everything here on earth from his heavens? And the sun has but one eye" (852-53). In addition to the ancients, the early moderns offer recastings 
of Polyphemus at the mirror that may have served as models for Góngora's Cyclops. The closest is Marino's identification of the sun with Polyphemus's eye in sonnet 4 of his Polifemeide:

In grembo al chiaro Alfeo vidi pur ora

l'imagin mia nel verde ombroso chiostro, ed a se stesso ha il suo splendor dimostro il vivo Sol, che la mia fronte onora.

[In the bosom of the clear Alfeo, amidst the green, shady bower, I saw just now my image, and to itself the living sun, which my forehead honors, has shown its splendor.] (my translation)

Góngora's Polyphemus supersedes Marino's in brightness and beauty as he places the sun in an inferior position to himself. ${ }^{19}$ Yet Polyphemus's ideal image is an illusion, his wholeness and harmony a fantasy. No matter how luminous, his eye-as-fetish is a mark of his monstrosity and so a mark of his vulnerability, since it is clearly one of the reasons for Galatea's rejection. An allusion to Polyphemus's blindness in stanza 43 foreshadows this self-deception: about to begin his lament, "el fiero jayán ciego [de amor]" (341) sits on a silent cliff, which in its figurative blindness reinforces the Cyclops'own ("linterna es ciega y atalaya muda," 344). In Lacanian terms, the fragmenting force of desire has indelibly marked him; his psychic instability is manifest in the very medium that serves for his celebration. The mirroring waters offer but a simulacrum of the self, a doubling that undermines knowledge of the self and, consequently, a true sense of personal identity. Polyphemus's instability is reflected textually at the very moment he looks into the waters, for in so doing he also "looks" into a multiplicity of poems that, like a fragmented prism, provides him fictional images with which to construct his own.

Ultimately, Polyphemus's ideal image is built on words, a splendidly modulated discourse in which he creates an identity at odds with his actions. In making his imagined exterior beauty conform to an inner beauty, he claims that love transformed him; but when goats eating his vines interrupt his lament, his gentleness disappears, his violence unleashed in a shower of fierce shouts and stones (59.470-71). A seductive performance is betrayed by a monstrous nature. ${ }^{20}$ No longer in the realm of his Imaginary, of narcissistic self-reflexivity, the Cyclops turns his sight outward to the lovers, who are running towards the sea, their bond broken by fear: 


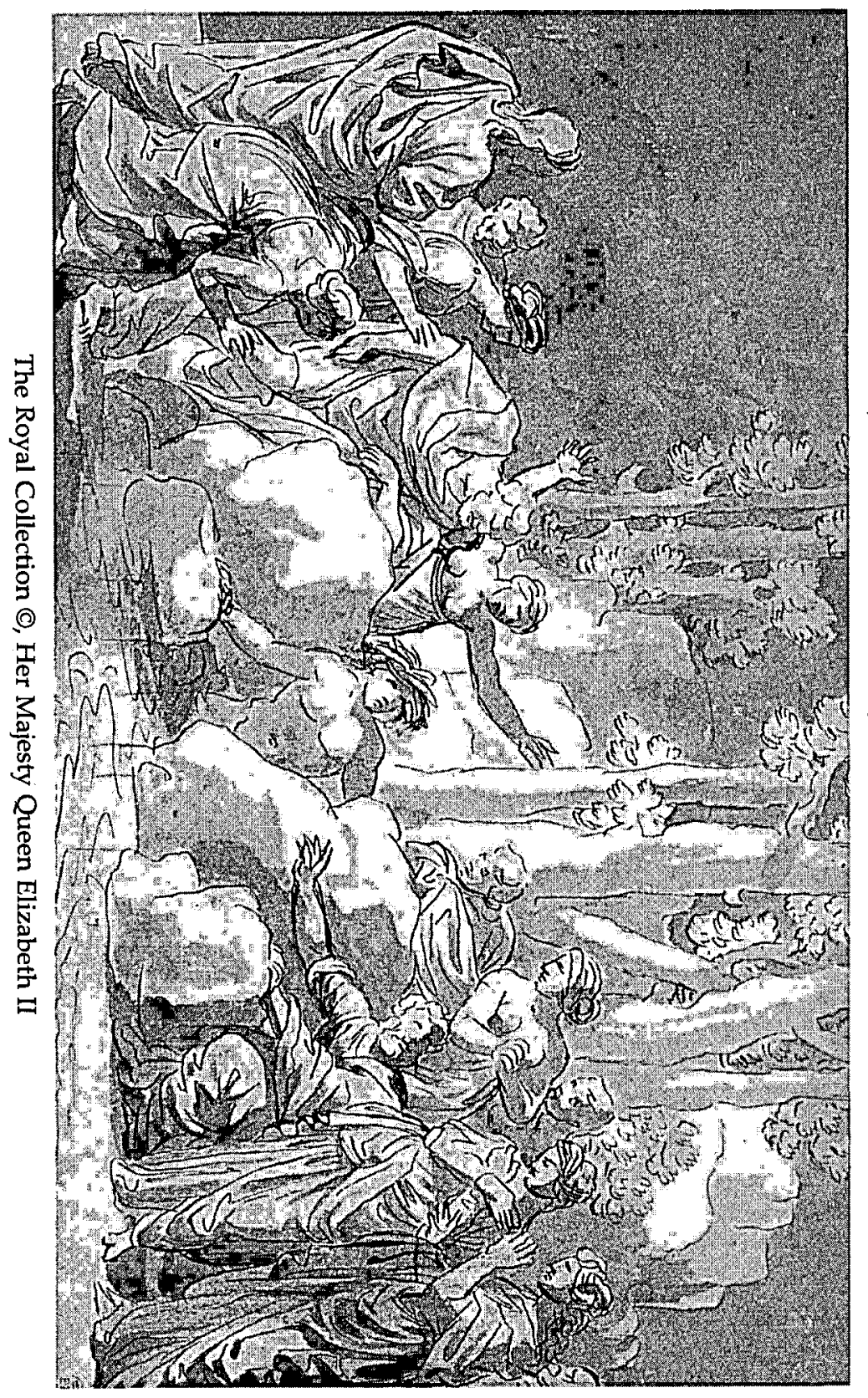

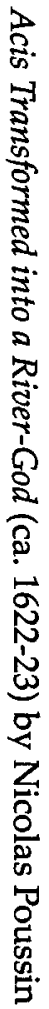


Viendo el fiero jayán, con paso mudo correr al mar la fugitiva nieve (que a tanta vista el líbico desnudo registra el campo de su adarga breve) y al garzón viendo, cuantas mover pudo celoso trueno, antiguas hayas mueve. (61.481-86)

As Polyphemus sees Acis, the darkness within erupts in jealous fury and he hurls a rock, killing his rival. The world of night overcomes the Cyclops-this, after all, is his true realm. His cave, depicted at the outset as "el melancólico vacío" (6.42) and "caliginoso lecho, el seno obscuro / ser de la negra noche" (5.37-38), circled by sad and somber nocturnal birds (5.39-40), is an emblem of this primeval, subterranean creature of Saturnine temperament. ${ }^{21}$.

Polyphemus is truly a "black sun," an ambiguous figure both dark and luminous. In her study of depression and melancholia, Julia Kristeva examines the image of the "black sun" in Gerard de Nerval's sonnet "El desdichado" in ways that are suggestive here. In the first quatrain of Nerval's sonnet, the lyric " $\mathrm{I}$ " portrays himself as follows:

"Je suis le ténébreaux, - le veuf, - l'inconsolé,
Le prince d'Aquitaine à la tour abolie;
Ma seule étoile est morte, - et mon luth constellé
Porte le Soleil noir de la Mélancolie."

["I am saturnine-bereft-disconsolate, / The Prince of Aquitaine whose tower has crumbled; / My lone star is dead-and my bespangled lute / Bears the Black Sun of Melancholia."] (Kristeva 141; emphasis in original)

Kristeva connects "tenebreux" ('dark' thus 'saturnine') with the Prince of Darkness, and as such with Pluto, "whose deformity caused the goddesses to flee (hence [the lyric speaker] is bereft [Nerval's "veuf" 'widower'])" (146). Kristeva also identifies the term with "night deprived of light. It conjures up the melancholy person's complicity with the world of darkness and despair" (147). For Kristeva, the "black sun" "takes up the semantic field of 'saturnine,'" but turns it "inside out, like a glove: darkness flashes as a solar light, which nevertheless remains dazzling with black invisibility" (147). The darkness of the melancholic mood is such that it flairs out like a dazzling sun, blinding in its power. So is Polyphemus's own darkness, its source a complex mix of monstrous violence and melancholia. The eye that he deems a sun is the very sign of his monstrosity, dark in its ugliness. As it flashes its brilliance, it flashes its monstrous darkness, a deformity that, like 
Pluto's, causes his own goddess to flee. At the end, the despondency of rejection blends with the rage of jealousy. With his desire not only rejected but betrayed, Polyphemus's darkness, which is as potent as his vision, bursts out: the melancholic and the monster fuse to kill and destroy. The nymph Galatea, back in her watery domain, can do nothing but pray to the ocean deities, who save Acis by endowing him with a new identity: they transform his bleeding body into a river.

\section{Notes}

${ }^{1}$ Focusing on the male gaze, María Cristina Quintero explores from a feminist perspective the relation between seeing and desiring for the construction of subjectivity in several Golden Age poems, including Góngora's sonnet "Mientras por competir con tu cabello." Quintero draws from theories of vision that I use in this study. I have found her important essay most useful.

${ }^{2}$ In this essay the gaze refers to the act of looking. The gaze as theorized by Jacques Lacan appears only briefly in note 11 to define Galatea's decentering effect on Polyphemus. For a useful study on the "gaze" and the "look," see Silverman.

${ }^{3}$ All references to the Polifemo will be to Dámaso Alonso's edition.

${ }^{4}$ As we will see, Acis does not give up the desired object as he displays himself to Galatea since, as he becomes the object of the nymph's looking, he looks back, complicating the third stage established by Freud.

${ }^{5}$ On enargeia, see Cave; on the use of enargeia in the Golden Age, see Smith ("The Rhetoric of Presence") and Barnard. Quintero applies enargeia to Góngora's sonnet "Mientras por competir con tu cabello" (498-99).

${ }^{6}$ Even though Smith allows catachresis its representational qualities, he claims that the codes of representation "resist totalization" (64). Commenting on the lines "tantos jazmines cuanta hierba esconde / la nieve de sus miembros" (179-80), he writes, "the image is emblematic of a shimmering linguistic surface which refuses to be anchored safely to the solid materiality of a pre-existing referent." In my analysis, the function of catachresis is more expansive.

"The catachresis "cristal mudo" connects with an earlier one in stanza 13 that renders Galatea as a rock crystal ("si roca de cristal no es de Neptuno," 103), an image that celebrates her resplendent whiteness ("cristal"), along with her callousness ("roca") in her role as "donna petrosa." Edward Friedman writes that "roca de cristal" "suggests a skin as soft as crystal [based on the implied metaphor of water as soft crystal] in a nymph who is hard as rock in disdaining her suitors" (62). According to Friedman, who also analyzes stanza 24, "[ $\mathrm{w}]$ hat begins as catachresis, the joining of unrelated images, becomes the foundation of a linguistic deep structure, a unity built from difference."

${ }^{8}$ Vilanova explains these verses: "El soplo del viento Favonio corrió lisonjeramente cortinas imprecisas e impalpables, vagas cortinas de volantes irreales y vanos, como si su leve soplo corriese suavemente unas cortinas 
invisibles en torno al lugar en donde descansaba Galatea dormida" (2:119). See also Parker 37, 68-69.

'On the fragmentation of the female body, see Vickers and Kritzman.

${ }^{10}$ See, especially, Alonso 3:97-100 and Parker 24-25, 64-66.

${ }^{11}$ In her rejection of Polyphemus, Galatea stands for the gaze in a Lacanian sense, a social construct that points to "the presence of others as such" (Four Concepts 84). The Lacanian gaze is a decentering force that places the subject within the field of desire (desire understood here as "unmet demand"). As Galatea scorns the Cyclops, she becomes a most powerful decentering presence, which he keeps alive in his imagination.

${ }^{12}$ Emilie Bergmann connects the inscription of Acis's image in Galatea's mind with Plato's account of perception and memory in his Philebus (249). According to Plato, "Memory and perception meet, and they and their attendant feelings seem to me almost to write down words in the soul. . . . The painter, who, after the scribe [within us] has done his work, draws images in the soul of the things which he has described" (in Bergmann 238).

${ }^{13}$ Cited in Quintero 492. Quintero explores the relations of seeing, desire, and knowledge in Garcilaso's "Con ansia estrema de mirar" (490-93).

${ }^{14}$ The Diccionario de Autoridades offers the following for lince (cited in its latinized form, lynce): "Se llama por semejanza el que tiene mui aguda la vista: y metaphoricamente el que tiene gran perspicacia y sutileza, para comprehender o averiguar las cosas dificultosas ù ocultas."

${ }^{15}$ The citation is from Smith, who suggests that in Góngora's poem the body "deprived of both interiority and essence, is all surface, all text" ("The Polifemo" 67).

${ }^{16}$ For my discussion of melancholia, I have profited from studies by Wittkower and Schiesari, in addition to Klibansky et al. I have also profited from Dolan on melancholia in Góngora's Polifemo and Soufas on melancholia in Golden Age texts, including the Polifemo.

${ }^{17}$ Teresa Soufas calls Polyphemus "the mighty poet faber whose song-withinsong is the only section presented in quotation marks as words directly attributable to their composer" (136). Soufas adds, "[Polifemo] parallels Góngora himself through his difference, his melancholia, and the solitary contemplation in which he writes his poetry."

${ }^{18}$ For these and other sources of Polyphemus's reflection, see Vilanova 2.589605.

${ }^{19}$ Tomasso Stigliani's Il Polifemo (1600) may have also served as a model, offering Polyphemus's gloating from another angle: "ei Polifemo grande, io picciol cielo" (he, a big Polyphemus; I, a small sky' [in Alonso 3:266; my translation]).

${ }^{20}$ Friedman interprets the passage as follows: "Polifemo's actions disprove his rhetoric. The professed reformation through love is an illusion. The destructive force cannot be contained, nor can violence be averted" (70). Anthony Cascardi points out Polyphemus's delusion and considers his song a "pastoral parody" (133-34).

${ }^{21}$ Soufas connects the cave to Saturn and melancholia (139-40). Dolan examines the cave in relation to Polyphemus's melancholic state, which she sees as a threat to pastoral (53-68). 


\section{Works Cited}

Alberti, Leon Battista. De Pictura. Trans. John R. Spencer, On Painting. New Haven: Yale UP, 1966.

Alonso, Dámaso. Góngora y el "Polifemo." 3 vols. Madrid: Gredos, 1967.

Barnard, Mary E. "Correcting the Classics: Absence and Presence in Garcilaso's Third Eclogue." Revista de Estudios Hispánicos 26 (1992): 320.

Bergmann, Emilie L. Art Inscribed: Essays on Exphrasis in Spanish Golden Age Poetry. Harvard Studies in Romance Languages, 35. Cambridge: Harvard UP, 1979.

Bowie, Malcolm. Freud, Proust, and Lacan: Theory as Fiction. Cambridge: Cambridge UP, 1987.

Branna Perlman, Julia. Looking at Venus and Ganymede Anew: Problems and

Paradoxes in the Relation Among Neoplatonic Writing and Renaissance Art.

Eds. Alina Payne et al. Cambridge: Cambridge UP, 2000.

Capellanus, Andreas. Andreas Capellanus on Love. Ed. and trans. P. G. Walsh.

London: Duckworth, 1982.

Cascardi, Anthony. "The Exit from Arcadia: Reevaluation of the Pastoral in Virgil, Garcilaso, and Góngora." Journal of Hispanic Philology 4 (1980): 119-41.

Cave, Terence. The Cornucopian Text: Problems of Writing in the French Renaissance. Oxford: Clarendon, 1979.

Dolan, Kathleen Hunt. Cyclopean Song: Melancholy and Aestheticism in Góngora's Fabula de Polifemo y Galatea. North Carolina Studies in the Romance Languages and Literatures, 236. Chapel Hill: Department of Romance Languages, 1990.

Erasmus. De duplici copia verborum ac rerum. Paris: Simonem Colinaeum, 1539.

Ficino, Marsilio. El libro dell'Amore. Trans. Sears Jayne. Commentary on Plato's Symposium on Love. $2^{\text {nd }}$ rev. ed. Dallas: Spring Publications, 1985.

The Letters of Marsilio Ficino. Trans. Language Department of the School of Economic Science, London, American ed. New York: Gingko, 1985.

Freud, Sigmund. "Instincts and Their Vicissitudes." The Standard Edition of the Complete Psychological Works of Sigmund Freud. Trans. James Strachey. Vol. 14. London: Hogarth, 1978.

. "Mourning and Melancholia." The Standard Edition. Trans. James

Strachey. Vol 14. London: Hogarth, 1978.

Friedman, Edward H. "Creative Space. Ideologies of Discourse in Góngora's Polifemo." Cultural Authority in Golden Age Spain. Eds. Marina S. Brownlee and Hans Ulrich Gumbrecht. Baltimore and London: Johns Hopkins

UP, 1995. 51-78.

Heath, Stephen. Questions of Cinema. Bloomington: Indiana UP, 1981.

Kristeva, Julia. Black Sun: Depression and Melancholia. Trans. Leon S. Roudiez.

New York: Columbia UP, 1989.

Klibansky, Raymond, Erwin Panofsky, and Fritz Saxl. Saturn and Melancholy: Studies in the History of Natural Philosophy, Religion and Art. New York: 
Basic Books, 1964.

Kritzman, Lawrence D. "Architecture of the Utopian Body: The Blasons of

Marot and Ronsard." The Rhetoric of Sexuality and the Literature of the

French Renaissance. New York: Columbia UP, 1991. 97-111.

Lacan, Jacques. Écrits: A Selection. Trans. Alan Sheridan. New York: Norton, 1977.

. The Four Fundamental Concepts of Psycho-Analysis. Ed. Jacques-

Alain Miller. Trans. Alan Sheridan. New York: Norton, 1981.

Marino, Giambattista. Poesie varie. Ed. Benedetto Croce. Bari: Laterza, 1913.

Mulvey, Laura. Visual and Other Pleasures. Bloomington: Indiana UP, 1989.

Moschus. See Theocritus.

Ovid. Metamorphoses. Ed. and trans. Frank Justus Miller. 1916. 2 vols. Loeb

Classical Library. Cambridge: Harvard UP, 1974.

Parker, Alexander A. 'Polyphemus and Galatea': A Study in the Interpretation of

a Baroque Poem. Austin: U of Texas P, 1977.

Petrarch. Petrarch's Lyric Poems: The Rime sparse and Other Lyrics. Ed. and trans. Robert M. Durling. Cambridge: Harvard UP, 1976.

Plato. Phaedrus. Trans. R. Hackforth. Cambridge: Cambridge UP, 1972.

Quintero, María Cristina. "'Con ansia estrema de mirar': Another Look at the Gaze in Spanish Golden Age Poetry." Revista de Estudios Hispánicos 34 (2000): 489-513.

Schiesari, Juliana. The Gendering of Melancholia: Feminism, Psychoanalysis, and the Symbolics of Loss in Renaissance Literature. Ithaca and London: Cornell UP, 1992.

Silverman, Kaja. The Threshold of the Visible World. New York and London: Routledge, 1996.

Smith, Paul Julian. "The Polifemo: Narrative and Catachresis." The Body Hispanic: Gender and Sexuality in Spanish and Spanish American Literature. Oxford: Clarendon, 1989. 60-67.

"The Rhetoric of Presence in Poets and Critics of Golden Age Lyric: Garcilaso, Herrrera, Góngora." MLN 100 (1985): 223-46. Revised version in Writing in the Margin: Spanish Literature of the Golden Age. Oxford: Clarendon, 1988. 43-77.

Soufas, Teresa Scott. Melancholy and the Secular Mind in Spanish Golden Age Literature. Columbia and London: U of Missouri P, 1990.

Theocritus. Theocritus, Bion and Moschus. Trans. A. Lang. London: Macmillan, 1889.

Vickers, Nancy. "Diana Described: Scattered Woman and Scattered Rhyme." Critical Inquiry 8 (1981): 265-279.

Vilanova, Antonio. Las fuentes y los temas del Polifemo de Góngora. 2 vols. Madrid: CSIC, 1957.

Virgil. Eclogues, Georgics, Aeneid 1-6. Ed. and trans. H. Rushton Fairclough. 1916. Loeb Classical Library. Cambridge: Harvard UP, 1965. Vol 1.

Wittkower, Rudolf and Margot. Born under Saturn: The Character and Conduct of Artists: A Documented History from Antiquity to the French Revolution. London: Weidenfeld and Nicolson, 1963. 